\title{
CB vs CVB - what is the difference between the tasks and roles of European and North American convention bureaux?
}

\author{
Natalia Latuszek
}

Natalia Latuszek is based at the Poznan University of Economics and Business, Poznan, Poland.

Received 30 November 2019 Revised 14 April 2020

27 June 2020

11 August 2020

Accepted 9 September 2020

() Natalia Latuszek.Published by Emerald Publishing Limited. This article is published under the Creative Commons Attribution (CC BY 4.0) licence. Anyone may reproduce, distribute, translate and create derivative works of this article (for both commercial and non-commercial purposes) subject to full attribution to the original publication and authors. The full terms of this licence may be seen at http:// creativecommons.org/licences/ by/4.0/legalcode

The paper was written under the project "The role of convention bureau in enhancing city competitiveness" granted by the Polish National Science Centre (NCN) no. 2015/17/N/HS4/ 00386.

\begin{abstract}
Purpose - The purpose of this paper is to analyse the divergence between the tasks and roles of convention bureaux (CB) in North America and Europe.

Design/methodology/approach - A survey among 55 CB' managers was conducted. A total of $75 \%$ of respondents represented institutions operating in European cities, 25\% - in North American ones. This research mainly focused on managers' opinions about the importance of tasks and roles performed by $C B$ and the degree to which the institutions manage to fulfil them. Therefore, importance-performance analysis was used in the study.
\end{abstract}

Findings - CB in North America and Europe broadly differ as to the characteristics of both groups of institutions. They include their time of operation, number of employees, annual budget and types of events that $C B$ try to attract to the cities that they represent. There are no such differences when it comes to the importance and performance of institutions' tasks and roles. The way in which managers evaluate them is quite similar because the respondents pay the closest attention to the roles of a marketer and an agent of a city played by a convention bureau. Differences lie in the meaning assigned by managers to the particular tasks of surveyed institutions.

Originality/value - The survey was carried out on a relatively small sample dominated by European institutions. However, the study attempts at investigating the roles and tasks of $C B$, with only few previous studies on this topic, including the ones comparing $C B^{\prime}$ activity in different countries or on different continents. Moreover, proposed recommendations might be useful for a large group of managers and do not have to be limited only to institutions from Europe and North America.

Keywords Convention bureau, CVB, Meetings industry, Europe, North America

Paper type Research paper

\section{Introduction}

Business tourism is an important topic in scientific literature; however, not enough attention is paid to convention bureaux (CB). The Scopus database has almost 40 scientific papers on $\mathrm{CB}$ [1]. Most of them deal with a particular activity of these institutions like online marketing, especially the performance of CB' websites (Cobos et al., 2009; Davidson and Keup, 2014; Feng et al., 2004; Ha and Love, 2005; Harrill and Stringam, 2008; Stepchenkova et al., 2010; Xiang et al., 2010) or overall use of information technologies (Yuan et al., 2006). Other research areas include relationships with stakeholders (Ford, 2011; Ford et al., 2011; Lee et al., 2015), with meeting planners (Weber, 2001) or the types of research conducted by such institutions (Masberg, 2000). However, there are only few papers considering CB activity in a more complex way (Getz et al., 1998; Morrison et al., 1998; Wang and Fesenmaier, 2007) and even fewer studies compare CB's operation in different countries or regions (Palmer and Bejou, 1995). Although there are relatively not many investigations referring to $C B$, their analysis proves that it is hard to have a homogeneous point of view on these institutions. 
The research presented in this paper is focused on CB in North America and Europe because of their divergent genesis and development (Crouch and Weber, 2002; Ford and Peeper, 2008; Gartrell, 1988; Ogonowska, 2017; Rogers, 2013; Spiller, 2002). Therefore, the organisations on these two continents may play other roles in cities and local meetings industries. The roles of CB are discussed in scientific literature (Getz et al., 1998; Morrison et al., 1998; Wang, 2008), but the investigations are focused mainly on entities in North America. Moreover, it has not been stated yet which CB's functions and tasks are the most important. These issues were taken into consideration and a survey was carried out to answer the question, "What are the differences between the roles of CB in North America and Europe?"

\section{Literature review}

\subsection{Definitions and roles of convention bureaux}

First, the nature of CB should be defined because there is no complex and universal/ general explanation of its role in the meetings industry and in cities. Even the former vice president of Destinations International [2] claims that "A lot of consumers use CVBs, but don't have any clue what they do" (Slaton, 2013). Therefore, several definitions are collected in Table 1 to illustrate subtle differences between them. According to these definitions, CB can be seen as, for example, forms of tourism alliance (Palmer and Bejou, 1995), umbrella organisations (Masberg, 1998), information providers (Beaver, 2005) or brokers (Park and Kim, 2017; Yuan et al., 2006), destination developers and liaison between visitors and meeting planners and the host destination ( $\mathrm{Ha}$ and Love, 2005) or a destination representative ( $\mathrm{Ha}$ and Love, 2005; Maier and Johanson, 2013; Rogers, 2013). A misunderstanding can also arise because CB are often identified with destination marketing or management organisations, known as DMOs (Cobos et al., 2009; DMAl's empowerMINT. com, 2016; Fall, 2004; Feng et al., 2004; Getz et al., 1998; Wang and Russo, 2007; Xiang et al., 2010). Such an approach may be reasonable, because destination marketing or promotion lies at the heart of many definitions of CB (Ford and Peeper, 2008; GoldenRomero, 2007; Maier and Johanson, 2013; Marques and Santos, 2017; Palmer and Bejou, 1995; Rogers, 2013; Swarbrooke and Horner, 2001).

In contrast, in the UNWTO's (2010) report these two types of institutions are differentiated. Here a convention bureau is defined as "a specific form of destination governance at local or regional level" and as an "entity responsible for promoting and organizing conferences, exhibitions, conventions, incentives and various events at the destination", whereas DMOs are entities which unite the local tourism industry "to develop and promote the destination" (UNWTO, 2010, p. 4). Moreover, Gartrell (1988) and Masberg (1998) underline that city marketing is only one of CB' responsibilities. A similar point of view is held by Destinations International - convention bureau focuses mostly on marketing, but its main mission is to develop cities in a long-term perspective (DMAl's empowerMINT.com, 2016).

In their operations, CB primarily deal with destination marketing, but many authors add wider context and indicate what purpose the marketing efforts should serve (Table 1). They should attract a higher number of events and visitors (Getz et al., 1998; Maier and Johanson, 2013; Marques and Santos, 2017), thus encouraging operation of local entrepreneurs (Lee and Lee, 2006) and finally contribute to fostering destination development (Gartrell, 1988). Another point of view is that a convention bureau acts as an information broker (Park and Kim, 2017; Yuan et al., 2006). Not only does it bring together local industry (Lee and Lee, 2006; Palmer and Bejou, 1995) but also supports communication outside the destination by providing information to meeting planners and visitors (Beaver, 2005; Ha and Love, 2005; Yuan et al., 2006). Moreover, a convention bureau can provide other services encouraging organisation of events (Baloglu and Love, 2005; UNWTO, 2010). 

$\begin{array}{ll}\text { Gartrell (1988), p. } 21 & \begin{array}{l}\text { Convention and visitors } \\ \text { bureaux }\end{array}\end{array}$

Palmer and Bejou (1995), p. 622

Getz et al. (1998), p. 331

Masberg (1998),

p. 67

Swarbrooke and

Horner (2001), p. 342

Beaver (2005), p. 110

Visitors and convention bureaux

Convention and visitors bureaux Convention and visitors bureaux

Convention bureaux

Convention bureaux

Ha and Love (2005), p. 45

Convention and visitors bureaux

Yuan et al. (2006), p. 326

Lee and Lee (2006), p. 115

Convention and visitors bureau

Convention and visitors bureaul housing bureau (2007), p. 98

Ford and Peeper (2008), p. 7 Convention and visitors bureaux UNWTO (2010), p. 4

Convention bureaux

Maier and Johanson Convention bureaux (2013), pp. 4-5
"Bureaus sell cities"

Convention and visitors bureau have one fundamental mission: to solicit and service conventions and other related group business and to engage in visitor promotions which generate overnight stays for a destination, thereby enhancing and developing the economic fabric of the community The visitors bureaux and CB can be regarded as the most developed form of local tourism marketing alliance in the USA. They vary in their authority and organisation and while most are nominally independent of government, some are administered as just another department within a county's authority. They also vary in size and responsibilities

CVBs are primarily destination marketing organisations, typically established at the community level for the purposes of fostering meetings and leisure travel A CVB is a cooperative or umbrella organisation for tourism marketing, development and administration in cities and towns An organisation responsible for marketing a city or area as a convention destination

Convention bureaux in the travel industry are usually funded either by a local, regional or national government agency, by a cooperative of hotels and conference facilities and sometimes by combination of both. Their function is to provide information to conference organisers about facilities and services in this field available in their countries or areas, e.g. LCB, the London Convention Bureau. Sometimes called convention and visitors bureau, it means exactly the same CVBs act as destination developers as well as destination representatives CVBs serve as the liaison between visitors and meeting planners and the host destination. Services include collecting information from host facilities, such as hotels, attractions, restaurants, and shops to provide information to potential visitors. CVBs provide support in planning meetings, conventions or trade shows so meeting organisers can make the best possible use of all the services, facilities and attractions that a destination can offer American CVBs, one layer of DMOs in the USA, are one of the important information brokers in tourism network. They act as a liaison in coordinating the segmented tourism businesses at a destination and in providing communication links to the consumer

The CVB, a comprehensive destination marketer, plays an important role in marketing destinations and their $\mathrm{C}$ and $\mathrm{E}$ (convention and exhibition) facilities, attracting more events to the destination and thus helping $\mathrm{C}$ and $\mathrm{E}$ providers reach their ultimate financial goal, making profits

A CVB acts like a centre of the $\mathrm{C}$ and $\mathrm{E}$ industry, including hotels, restaurants, convention facilities, attractions, tour operators as well as commercial resources in its orbit

Originally, bureaus were created in large US cities to promote their destination to convention groups needing hotel rooms and meeting facilities. As the name implies, the term visitors refers more to the tourism promotion

$\mathrm{A} C V B$ is an organisation that both by law and by design is responsible for marketing destination

A convention bureau is a specific form of destination governance at local or regional level. It is a type of organisation with a distinct structure and role, typically for urban destinations but also common for rural, coastal and mountain areas. A convention bureau is the entity responsible for promoting and organizing conferences, exhibitions, conventions, incentives and various events at the destination. It could be a non-profit private-public partnership, a company funded by the private sector, a department of public authority or even a private sector trading

A convention bureau represents the city or local municipality in its desire to market the city and generate convention attendees based on promotional events and other associated activities. The convention bureau and tourism authority are usually an independent not-for-profit entity funded from several sources

(continued) 


\section{Table 1}

Rogers (2013), p. 120

Convention bureaux/ convention and visitors bureaux

Marques and Santos (2017), p. 426 Park and Kim (2017), p. 381
Convention and visitors bureaux Convention and visitors bureaux
The bureaux are established as not-for-profit organisations, controlled by management board, to fulfil a strategic marketing role and to be "official" voice of the destination they represent Specialised organisations in cities promotion (their resources and attractiveness) to captivate the largest possible number of events CVBs are important information brokers and disseminators in the local tourism industry and act as a layer of destination management in the USA. With financial support from the local community, one of the critical goals of CVBs is to promote their destinations to both leisure and business travellers

Source: Own elaboration on basis of references listed in the first column

The variety of approaches presented in the definitions mentioned above indicates how many different roles $\mathrm{CB}$ can play in cities. According to the research conducted by Kovačević (2017), activities of this institution can be classified into three main categories:

1. coordination of destination stakeholders;

2. destination marketing; and

3. destination sales.

Gartrell (1992 after Wang 2008) and Morrison (2019) provide more detailed functional fields related, for example, to promotion and marketing, coordination, leadership, communication and representation of divergent groups of interests. A detailed list of tasks is presented by International Congress and Convention Association (ICCA, n.d.). A few other authors investigate the roles of CB (Gartrell, 1988; Getz et al., 1998; Morrison et al., 1998; Vallee 2008 after: Davidson and Keup, 2014) and propose their own lists of functions or operational areas. Wang (2008) summarises such lists and research and claims that CB can act in a city as a (Wang 2008, p. 194):

- destination/community marketer/promoter;

- destination image/brand developer;

- industry coordinator;

- advocate/supporter/facilitator of tourism projects;

- economic driver;

- quasi-public representative;

- builder of community pride;

- partnership/alliance builder;

- destination planner/manager; and

- destination product developer.

Subject matter authors concentrate mostly on roles of CB in the local environment (except for Weber, 2001), whereas practitioners also stress their role for meetings organisers (DMAl's empowerMINT.com, 2016; Loomis, 2018). This is summarised by the President of Destinations International: "CVBs can show advantages to a destination that a planner may not have been aware of and wouldn't find anywhere else" (Loomis, 2018). All the issues mentioned previously show that convention bureau has a wide scope of activity and the differences among CB can be observed not only in the range of responsibilities but also organisational issues (Beaver, 2005; Palmer and Bejou, 1995; UNWTO, 2010). 


\subsection{History of convention bureaux}

Differences in how the role of $\mathrm{CB}$ is understood may result from divergent genesis of this institution all over the world. Such organisations originated in the USA at the turn of 20th century (Figure 1). Many factors (like urban development, transportation improvement, associations' foundation and growth) caused cities to attempt to attract association meetings because of the expected benefits from their organisation. Therefore, they started to employ full-time salespeople to travel around the country and encourage decision makers to organise their events in a particular city. For the first time this happened in Detroit in 1896, the year in which the first convention bureau is believed to have been founded. Soon the solution was applied in other cities. In the second half of the 20th century the institutions broadened the range of their activity and also focused on leisure travellers (Figure 1). This transformation manifested itself in the change of the organisations' name from "convention bureaux" to "convention and visitors bureaux" (Ford and Peeper, 2008; Gartrell, 1988; Rogers, 2013; Spiller, 2002).

The meetings industry had similar growth potential in Europe. Even earlier the Congress of Vienna took place (1814-1815), which according to Rogers (2013) can be regarded as one of the first international congresses. However, further industry development was inhibited especially by the First and Second World Wars. This was also the case for the foundation of CB (Figure 1). Although the first European convention bureau was established in 1905 in London (Marques and Santos, 2017), such organisations began to be established in the second half of the 20th century on the Old Continent and even later in Eastern Europe after 1989 (Ogonowska, 2017; Rogers, 2013; Spiller, 2002).

Before the foundation of $\mathrm{CB}, \mathrm{DMO}$ s were started in Europe. First entities were established at the same time as first CB in North America, because at the end of the 19th century DMOs started to operate in three Swiss cities - in Zurich, Basel and Bern (Seiser, 2008). As previously mentioned, the history of CB in Europe is shorter. Moreover, they were formed mostly as independent organisations specialised in the meetings industry. In consequence, two institutions existed in a number of cities: one responsible for leisure tourism (DMO) and

Figure 1 Foundation and evolution of convention bureaux in the USA and Europe

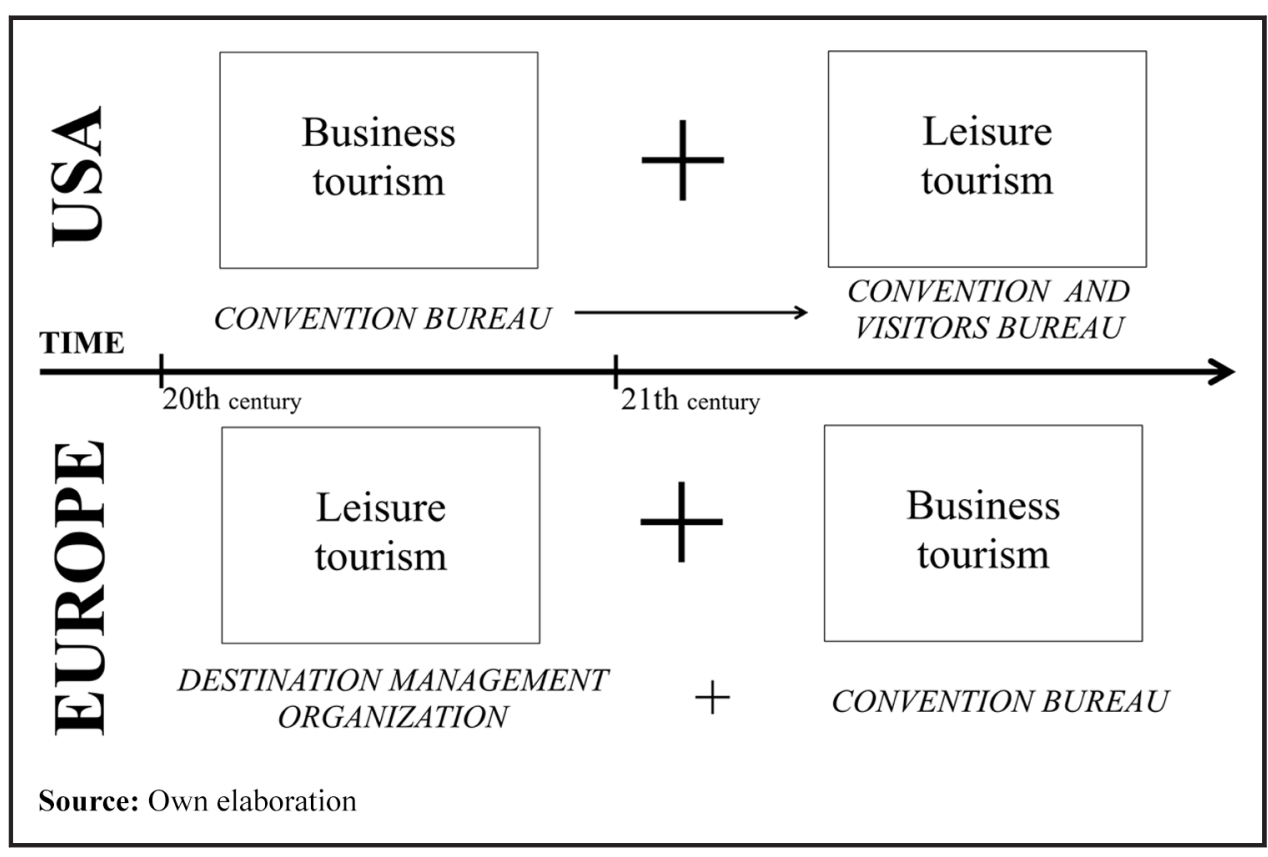

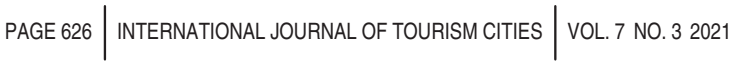


the other - for business tourism (convention bureau). Thus, two ways of CB' formation and evolution may be seen: the North American and the European ones, both presented in Figure 1.

\subsection{Differences between European and North American convention bureaux}

The differences among CB are already indicated in their definitions and can stem from divergent genesis of such organisations all over the world. Distinctions may be seen mostly between institutions from Europe and North America. Ford and Peeper (2008, pp.12-22) emphasise that there are three key differences between these two groups of $\mathrm{CB}$. These distinctions refer to:

1. size of institution and destination which it represents;

2. funding patterns; and

3. specific operational activities.

However, detailed analysis of authors' considerations shows that there are many more differences (Table 2). They especially result from distinct operational areas, which is caused by two other ways of $\mathrm{CB}^{\prime}$ foundation and evolution (both ways are described in the previous part of this paper). European CB' activities are focused mostly on business tourism or the so called meetings, incentives, conventions or conferences, exhibitions or events sector, whereas North American institutions also concentrate on the leisure tourism segment [3].

This means that entities in Europe operate in B2B relations (Leszczyński et al., 2015) and US CB also capture the B2C market. However, research conducted by Destinations International on 521 institutions from all over the world shows that almost $75 \%$ of organisations capture both markets (Destinations International, 2019). According to Ford and Peeper (2008) European institutions are involved mostly at the stage of marketing and bidding for meetings, with a smaller contribution made to organising events. CB in the USA and Canada offer a wider set of services and need a higher annual budget and more employees than other CB (Ford and Peeper, 2008; Palmer and Bejou, 1995). According to Destinations International (2020), convention and visitors bureaux (CVBs) had a total budget of US $\$ 3.28 \mathrm{~m}$ (it is the median destination organisation budget). Data on the budget of members of European Cities Marketing are not widely available.

Also, a funding pattern is different in Europe and North America. A common basis of American institutions' budgets is bed tax revenues (also called room or tourism

\section{Table 2 Differences between USA and non-US convention bureaux}

\begin{tabular}{|c|c|c|}
\hline Differences & US convention bureaux & $\begin{array}{l}\text { non-US CB } \\
\text { (especially European CB) }\end{array}$ \\
\hline Operational area & Leisure and business tourism & Business tourism \\
\hline Represented area & City or region & City or region or country \\
\hline \multirow[t]{3}{*}{ Size } & Higher annual budget & Lower annual budget \\
\hline & Higher number of employees & Lower number of employees \\
\hline & Bigger local meetings industry & Smaller local meetings industry \\
\hline \multirow[t]{2}{*}{ Main market } & Domestic & International \\
\hline & $\mathrm{B} 2 \mathrm{~B}$ and $\mathrm{B} 2 \mathrm{C}$ & $\mathrm{B} 2 \mathrm{~B}$ \\
\hline \multirow[t]{2}{*}{ Priority meetings to bid for } & Association meetings & \multirow[t]{2}{*}{ Association meetings } \\
\hline & $\begin{array}{l}\text { Corporate events } \\
\text { SMERF }\end{array}$ & \\
\hline Funding & Bed tax & $\begin{array}{l}\text { Grants or allocation from government membership fees } \\
\text { Bed tax }\end{array}$ \\
\hline \multirow[t]{2}{*}{ Activities } & Marketing to the tourist and leisure travellers & Sales to the meetings market \\
\hline & Sales to the meetings market & Services for the meetings market \\
\hline
\end{tabular}


tax - Ford and Peeper, 2007, 2009). However, they can receive funding from other public or private sources (DMAI, 2015). The idea of bed tax was firstly reported in New York and established in Las Vegas (Wood 2002 after: Ford and Peeper, 2007) and the main concept refers to financing marketing efforts to attract new visitors from small amounts paid by tourists who had already come and spent a night in a particular city. This solution is becoming more common in Europe, but CB' budgets generally comprise fees from local members and grants received from governmental units (Ford and Peeper, 2008; Palmer and Bejou, 1995). The funding pattern is mostly related to the form in which a convention bureau was set up and its relationships with local governments and DMOs. Institutions in Europe and North America may have a wide range of organisational forms (DMAI, 2015; UNWTO, 2010) with most of them being non-profit (DMAI, 2015).

Geographical location also has other direct consequences for CB' operation. North American institutions focus more on national meetings because of the big domestic market (Table 2; DMAI, 2015). Simultaneously, they differentiate the types of event to bid for. They are interested in associations meetings, corporate events and the Social, Military, Educational, Religious, Fraternal segment, but they are also open to sport, political and cultural events. For European CB international associations meetings are a priority [4]. This does not mean that they do not attract other events, but probably they must narrow their activities due to their limited financial and human resources. Moreover, US organisations generally represent bigger cities and have to manage bigger local networks of business and leisure tourism entrepreneurs and meet the needs of a higher number of stakeholders. The last difference is the fact that European CB are created at local, regional and national level (Beaver, 2005; Crouch and Weber, 2002), whereas there is no need to establish American Convention Bureaux.

Comparison was made based only on literature analysis and the author is aware that it is a big simplification, because on the one hand CB may strongly differ in one country, especially that there are approximately 1,450 organisations in the USA (DMAl's empowerMINT.com, 2016). On the other hand, distinctions between institutions all over the world may not be so sharp due to globalisation and international competition in which they are taking part. For example, European leaders on the meetings market like Paris or Vienna may share more similarities with big American cities than with a location on the same continent. Nevertheless, previous studies are a reliable source of information and the already mentioned differences refer to many European and North American CB (they show some general patterns), but obviously not to all of them.

The literature analysis confirms the need to conduct further research into convention bureau activity in various parts of the world. Moreover, there are several reasons why both scientists and practitioners may want to compare European and North American institutions empirically. Firstly, few studies focus on convention bureau outside the USA and Canada; therefore, organisations in other locations need further studies. Secondly, Palmer and Bejou (1995) prove that economical, political and social conditions in particular countries may affect convention bureau activity, for example, when it comes to meeting the needs of their stakeholders. Thirdly, Getz (2003, p. 9) claims that competitive advantage on the international meetings market can be achieved through one of the following main three strategies:

1. expand capacity;

2. improve quality; and

3. bid more effectively.

The first option is mainly beyond the scope of convention bureau. In the second case, they can only improve the quality of their own services or stimulate local industry through 
organising workshops and recommending standards. Thist means that they should concentrate mostly on bidding. Therefore, greater effort should be put into investigating the role of convention bureuax in this process. Moreover, international comparisons can be useful because they show differences between CB and thus potential source of advantage. It should help institutions to mark out cities they represent on the international meetings market. For new locations in this industry, this should provide some directions on how to enter international competition. It is important because, for example, according to Ogonowska (2017), Asian or African meetings industries show considerable growth potential.

\section{Method}

Because European and North American CB do not have the same origin and history and because there are differences between them as described in the subject literature, it is assumed that these institutions may play distinct roles in cities that they represent. However, this problem has not been researched yet. There are only few papers that refer to functions of $\mathrm{CB}$ and they focus on these organisations generally or on their regional characteristics. Therefore, the aim of the exploratory study presented in this paper was to investigate the differences between the roles of CB in North America and Europe.

The author narrowed the lists of $\mathrm{CB}^{\prime}$ activities presented in literature to five main roles of such institutions: the agent, marketer, coordinator, representative of the meetings industry and leader. CB as agents represent their cities, especially when it comes to bidding for meetings. As was earlier presented in the definitions of this term, CB are also responsible for city promotion as meetings destination. Such actions need to be coordinated within the local meetings industry and lobbying for this sector in the city. CB may also play the role of a leader that guides the development of the industry. The roles mentioned previously were used in the survey to analyse the presumptive differences between European and North American $\mathrm{CB}$.

\subsection{Survey on convention bureaux' roles}

A survey was part of a wider research project on the roles of convention bureau, coordinated by the author of this paper. The project was created to analyse the impact of CB on cities' competitiveness with special focus on Polish institutions. It included, inter alia, an international, online survey among representatives of CB from cities listed in an ICCA ranking. A questionnaire was sent to 290 managers in June and July 2016, with responses from 73 institutions. A total of 41 respondents represented Europe and 14 represented USA and Canada [5]. They were classified into further analysis in this paper. This group of respondents included presidents, vice presidents, directors and managers. Almost $42 \%$ of them held the highest position in CB. The rest of respondents managed sales department (16\%), research department (9\%), congress department (5\%) or other departments (9\%), for example, marketing, strategy and communication and fairs and exhibition departments) or provided no answer for this question. Further in this paper term "respondents" and "managers" will be used interchangeably

Managers completed an emailed questionnaire that consisted of two parts. Firstly, respondents were asked about their opinion on the importance of CB' tasks and the way in which the institution that they represented fulfilled them. They used a list of twelve tasks, prepared on the basis of literature analysis and a five-point scale to assess the importance and performance of each activity. Every task was ascribed to one of the five roles of CB for further analysis (the list of tasks and roles is included in Table 3). In the next part of the questionnaire respondents provided general information about their organisations, for example, about the time of operation, organisational form, number of employees and annual budget. 
Table 3 Roles and tasks of convention bureaux

\begin{tabular}{|c|c|}
\hline Roles & Tasks \\
\hline Agent & $\begin{array}{l}\text { 1. Answering the inquiries of events organisers/hosts } \\
\text { 2. Searching for request for proposals and making bids } \\
\text { 3. Mediating between organisers/hosts of events and entrepreneurs from the local meetings industry } \\
\text { 4. Cooperating with other convention bureaux }\end{array}$ \\
\hline Leader & $\begin{array}{l}\text { 5. Providing direction for the local meetings industry's development } \\
6 \text {. Conducting research on the local meetings industry }\end{array}$ \\
\hline Coordinator & $\begin{array}{l}\text { 7. Creating the destination meetings industry product (combining the local entities' offers) } \\
\text { 8. Coordinating local meetings industry's activities and creating local cooperation environment }\end{array}$ \\
\hline Representative & $\begin{array}{l}\text { 9. Indicating the importance of the meetings industry in a city } \\
\text { 10. Mediating between local meetings industry entrepreneurs and local government } \\
\text { 11. Mediating between entrepreneurs in the local meetings industry and related industries (e.g. culture, finance, recreation) }\end{array}$ \\
\hline Marketer & 12. Promoting the destination meetings industry product \\
\hline
\end{tabular}

Source: Own elaboration

The way in which the questionnaire was built enabled using the importance-performance analysis (IPA) in the further research steps. This method was originally designed for measuring consumer satisfaction with services, which was perceived as a combination of the importance of services' attributes and performance in providing them by a particular company or companies (Martilla and James, 1977). The IPA has already been used in a variety of research projects into, for example, tourism or business tourism area. The papers concerned, for example, the determination of a city's attractiveness in the meetings market (Go and Zhang, 1997) and the competitiveness studies or research into the attractiveness of tourist regions (Caber et al., 2012; Enright and Newton, 2004; Mihalic, 2013).

The biggest value of the IPA is that it is a transparent, graphical data presentation on IPA gird and researchers can offer practical recommendations. Each of the four squares on the grid is related to the proposed solution:

1. concentrate here - a quarter with high scores of importance and lower performance;

2. keep up the good work - high importance and high performance;

3. low priority (attributes) - low importance and low performance; and

4. possible overkill - high performance and lower importance.

In this project, the IPA was used to prioritise tasks of $\mathrm{CB}$ and to compare their roles in Europe and North America, which is an original attempt in case of this method. The quarters' boundaries in the IPA grid were calculated as mean values of the importance and performance for each group of CB (more information about the method can be found in Martilla and James, 1977). Moreover, the Mann-Whitney's $U$ test was done to show the significance of differences between appraisals given by managers from Europe and North America. This test is suitable for comparing two small samples.

\subsection{Sample characteristic}

Data analysis started with characterising the sample. Further in the paper the following abbreviations will be used: European convention bureaux - CB; North American convention and visitors bureaux - CVB. Characteristics of both groups of institutions show the same differences as in literature analysis (Table 4). CBs are less experienced than CVBs because their average time of operation is almost three times shorter. When the research was conducted, CBs and CVBs had operated for 15 and 59 years, respectively. European entities also manage more limited resources. They employ nine people on average and 
Table 4 Characteristics of European and North American convention bureaux

\begin{tabular}{lcccc}
\hline Roles & \multicolumn{2}{c}{ European CB } & \multicolumn{2}{c}{ North American CVB } \\
\hline Number of institutions in the sample & 41 & - & 14 & - \\
Average time of operation [in years] & 15 & {$[n=38]$} & 59 & {$[n=13]$} \\
Average number of full-time employees & 9 & {$[n=41]$} & 89 & {$[n=14]$} \\
Organisational forms: & & {$[n=40]$} & & {$[n=14]$} \\
- Non-profit public-private partnership & $52.5 \%$ & & $64.3 \%$ & - \\
- Department of public authority & $17.5 \%$ & - & $0 \%$ & - \\
- Private sector trading & $2.5 \%$ & - & $0 \%$ & - \\
- Company founded by private sector & $5.0 \%$ & - & $0 \%$ & - \\
- Others & $22.5 \%$ & - & $35.7 \%$ & - \\
Average annual budget [in USD] & $1,394,943$ & {$[n=27]$} & $33,786,169$ & {$[n=14]$} \\
Types of events to bid for: & - & {$[n=41]$} & - & {$[n=14]$} \\
- Business & $100.0 \%$ & - & $100.0 \%$ & - \\
- Political & $51.2 \%$ & - & $85.7 \%$ & - \\
- Sport & $43.9 \%$ & - & $100.0 \%$ & - \\
- Cultural & $41.5 \%$ & - & $92.9 \%$ & - \\
- Others & $24.3 \%$ & - & $14.3 \%$ & - \\
Source: Own elaboration & & & &
\end{tabular}

have US $\$ 1 \mathrm{~m}$ in their annual budgets, whereas CVBs have 89 full-time employees and US $\$ 34 \mathrm{~m}$ for yearly operation.

European institutions are more diversified than North American entities when it comes to organisational forms (Table 4). CBs represent all forms listed in the UNWTO (2010) report, but both groups are dominated by non-profit public-private partnerships (more than half of all institutions taking part in the research). Respondents also frequently indicated the answer "others", which includes, for example, non-profit public or private entities, foundations and companies that are subordinate to tourist boards or other local governmental bodies. The last piece of information refers to the types of events that CB bid for. All institutions try to attract business events (meetings) and European entities are focused mostly on this type. CVBs diversify their actions and they also concentrate on sport, cultural and political events. In the category "others", respondents mentioned especially scientific- or university-related events and private events.

\section{Results}

Research primarily investigated on CB' tasks and roles in cities and local meetings industries. Its results are presented in Table 5, Figures 2 and 3 and they are fairly high, because all scores are above three- on a five-point scale. The most important task for CBs consists in answering the inquiries of events organisers (task no. 1). The same activity is characterised by the highest level of performance. High scores are also ascribed to city promotion (no. 12) and indicating the meaning of the meetings industry (no. 9). A similar situation occurs for CVBs, but the most important task is searching for request for proposals and making bids (no. 2). Promoting the destination (no. 12) is an activity performed to the highest extent. The lowest results of the importance and performance in both groups refer to mediating between entrepreneurs in the local meetings industry and related industries (no. 11).

\subsection{Similarities}

Boundaries on the IPA grid (Figure 2) for both groups of CB are quite similar and the same recommendations are given to eight tasks. These suggestions refer mostly to continuation of previous activities. Efforts should still be focused on four tasks that are located in quarter B (keep up the good work). It includes tasks no. 1 (answering the inquiries of events 
Table 5 Average values of the importance and performance for European and North American convention bureaux

Roles and tasks

European

Average values

Agent

1. Answering the inquiries of events organisers/hosts

2. Searching for request for proposals and making bids

\begin{tabular}{cccccc}
\multicolumn{2}{c}{$C B$ I } & \multicolumn{5}{c}{ CVB } \\
\hline 4.26 & 4.39 & 0.13 & 4.23 & 4.38 & 0.14 \\
4.90 & 4.76 & 0.15 & 4.86 & 4.64 & 0.21 \\
$4.56^{*}$ & 4.20 & 0.37 & $5.00^{*}$ & 4.57 & 0.43 \\
4.44 & 4.17 & 0.27 & 4.14 & 4.21 & -0.07 \\
& & & & & \\
3.66 & 3.90 & -0.24 & 3.50 & 3.50 & 0.00 \\
3.85 & 4.33 & 0.48 & 4.04 & 4.39 & 0.36 \\
4.44 & 3.95 & 0.49 & 4.36 & 4.07 & 0.29 \\
4.22 & 3.76 & 0.46 & 4.43 & 4.00 & 0.43 \\
3.99 & 4.31 & 0.32 & 4.12 & 4.07 & -0.04 \\
4.22 & 3.83 & 0.39 & 4.14 & 4.23 & -0.09 \\
$4.41^{*}$ & 4.15 & 0.26 & $4.00^{*}$ & 4.00 & 0.00 \\
3.65 & 4.10 & 0.45 & 3.93 & 4.05 & 0.12 \\
4.80 & 4.22 & 0.59 & 4.86 & 4.64 & 0.21 \\
4.08 & 3.65 & 0.43 & 3.86 & 3.86 & 0.00 \\
& & & & & \\
3.43 & 3.08 & 0.35 & 3.43 & 3.29 & 0.14 \\
& & & & & \\
4.83 & 4.59 & 0.24 & 4.86 & 4.71 & 0.14 \\
4.83 & 4.59 & 0.24 & 4.86 & 4.71 & 0.14
\end{tabular}

3. Mediating between organisers and entrepreneurs of events from the local meetings industry

4. Cooperating with other convention bureaux

Leader

5. Providing direction for local meetings industry's development

6. Conducting research on the local meetings industry

\section{Coordinator}

7. Creating the destination meetings industry product

8. Coordinating activities and creating cooperation environment

Representative

9. Indicating the importance of the meeting industry in a city

10. Mediating between meetings industry entrepreneurs and local government

11. Mediating between entrepreneurs in the local meetings industry and related industries

Marketer

12. Promoting the destination meetings industry product

Notes: $I$ = Average importance; $\mathrm{P}=$ Average performance; Gap = Average importance-average performance. ${ }^{*}$ For these tasks, significant differences were observed in the appraisals of importance and/or performance - $p$ values below 0.05 according to Mann-Whitney's U test calculated in STATISTICA

Source: Own elaboration

\section{Figure 2 IPA grid for European and North American convention bureaux - tasks}

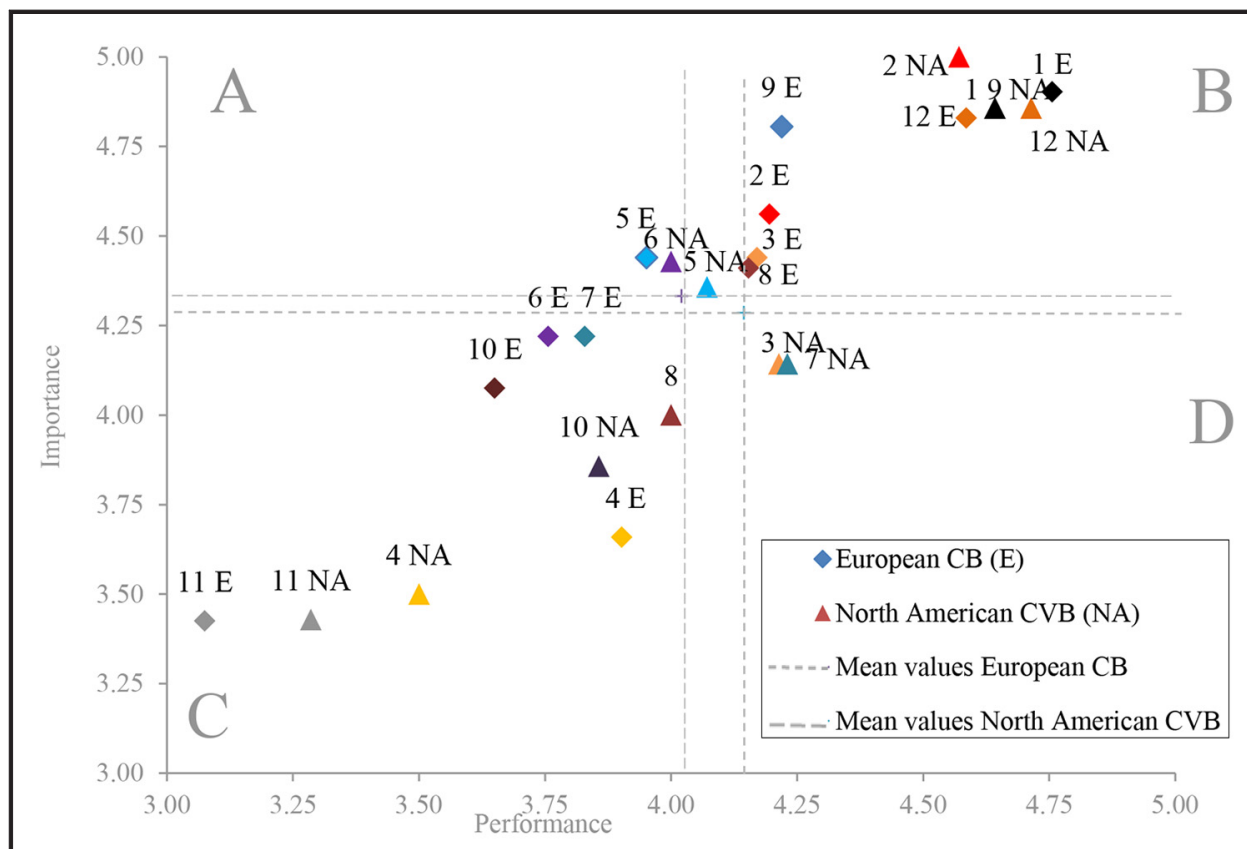

Source: Own elaboration 


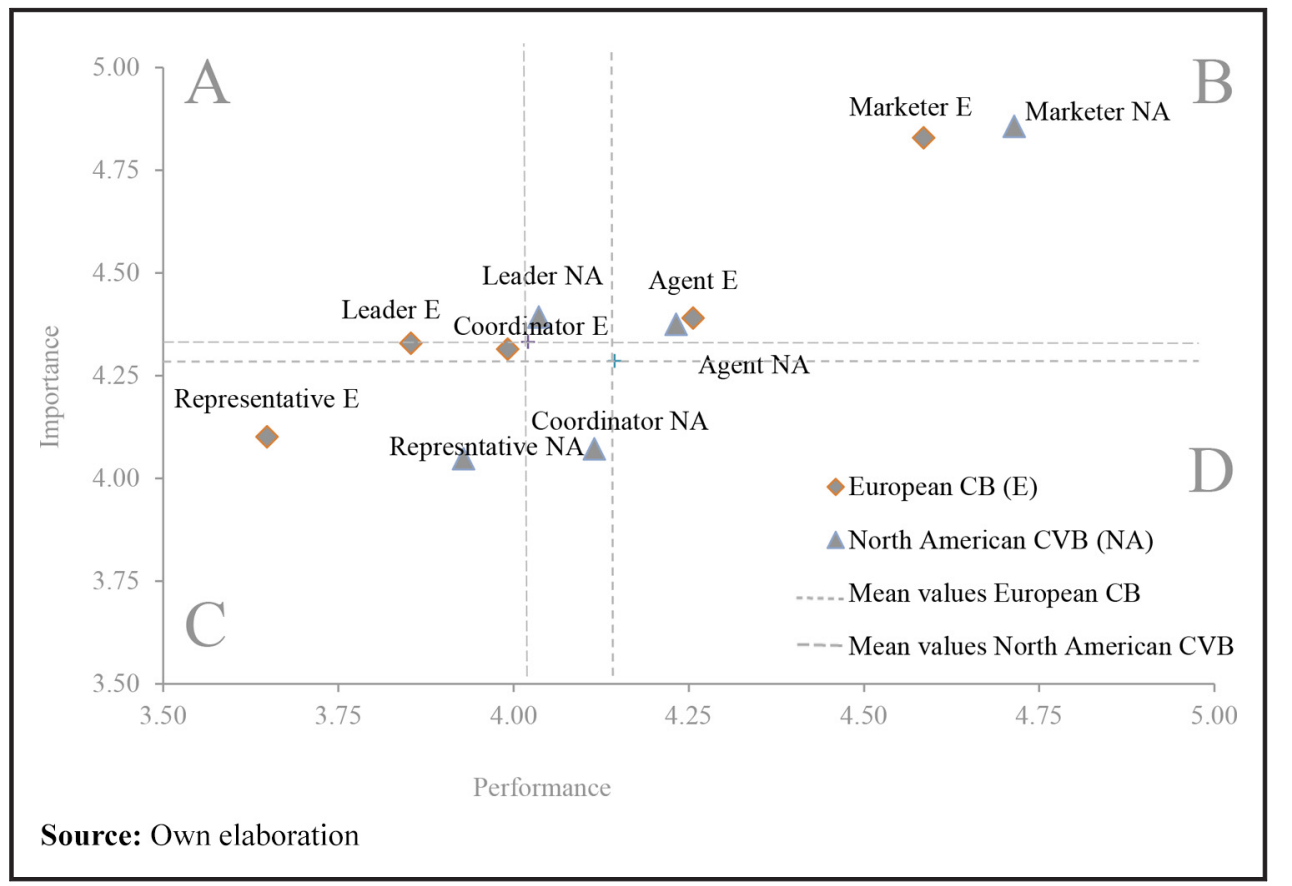

organisers/hosts), 2 (searching for request for proposals and making bids), 9 (indicating the importance of meeting industry in a city) and 12 (promoting the destination meetings industry product). Much lower priority (quarter $\mathrm{C}$ ) is ascribed to three duties: cooperation with other CB (no. 4), mediating between meetings industry entrepreneurs and local government (no. 10) and mediating between entrepreneurs in the local meetings industry and related industries (no. 11). One task demands more concentration because of its location in quarter A (concentrate here). Institutions in both continents should pay closer attention to providing direction for local meetings industry's development (no. 5).

\subsection{Differences}

Different recommendations according to the IPAs interpretation should be provided for four tasks (Figure 2). North American respondents claim that they need to focus more on conducting research on the local meetings industry (task no. 6 in quarter A), whereas for managers from Europe this duty has a lower priority (quarter $\mathrm{C}$ ). On the contrary, CVBs pay less attention to tasks no. 3 and 8. Coordination of local meetings industry's activities and creation of local cooperation environment (no. 8) has no great meaning for CVB managers (quarter $\mathrm{C}$ ), although European respondents see this activity as an important one and performed to the high extent (quarter B). They have the same opinion for task no. 3. For CVBs, mediating between event organisers and entrepreneurs from the local meetings industry (task no. 3 in quarter D) has a higher score for performance than importance; therefore, it may need special attention from managers, who maybe they should abandon this responsibility. A smaller difference in interpretation occurs for task no. 7, because creation of city meetings industry product is located in quarter $C$ for $C B$ and in quarter $D$ for CVBs.

It was tested (using the Mann-Whitney's $U$ test) whether differences between appraisals of tasks' importance and performance done by CB and CVB managers were significant (Table 5). Such results were achieved only for three cases: scores of importance for task 
no. 2 and 8 and performance for task. no. 9. This confirms that managers hold slightly different opinions as to the tasks performed by these institutions and does not change the way in which the IPA grid should be interpreted. However, the results underline the differences in the viewpoints on the meaning of coordination task of CB (no. 8). This also shows that CBs may slightly underestimate the role of active searching for requests for proposals and making bids (no. 2) and CVBs perform slightly better in indicating the importance of the meetings industry (no. 9), although both groups of institutions follow the same strategy for these two tasks.

\subsection{Roles}

Recommendations according to the roles of $\mathrm{CB}$ are quite similar for both groups of institutions (Figure 3). The highest scores are ascribed to the function of marketer. The same quarter has results for the agent, but scores of this function are diminished by the scores for task no. 4 (cooperation with other CB). Respondents in both groups also hold the same opinion according to the role of representative, because this function has a low priority. CVBs should probably put less effort into acting as coordinators and focus more on being leaders in the local meetings industry. Recommendations for $\mathrm{CBs}$ for these roles are not so clear because the results for them are located near the boundary between quarters $A$ and $\mathrm{C}$.

\section{Findings and discussion}

It can be stated that the research results mostly confirm the current state of knowledge about the activity of $\mathrm{CB}$. According to the majority of definitions of this term, the main operational area is city marketing (Ford and Peeper, 2008; Golden-Romero, 2007; Maier and Johanson, 2013; Marques and Santos, 2017; Palmer and Bejou, 1995; Rogers, 2013; Swarbrooke and Horner, 2001), together with attracting events (Gartrell, 1988; Getz et al., 1998; Lee and Lee, 2006; Maier and Johanson, 2013; Marques and Santos, 2017). Being an information broker (Park and Kim, 2017; Yuan et al., 2006) or a liaison (Ha and Love, 2005) between the local meetings industry and events hosts is more about answering the inquiries, making bids and searching for request for proposals than mediating in relationships between entrepreneurs and associations. Therefore, the role of CB should be more fundamental at the early stages of winning a meeting and less important during the negotiations and event organisation. Simultaneously, this does not mean that other functions of such institutions or their operational areas listed in literature (Getz et al., 1998; Kovačević, 2017; Wang, 2008) or used in the research are meaningless. The results show that they are also important but they play a supplementary role to the function of marketer and agent.

According to the distinction between European and North American CB, characteristics of both groups confirm many differences among them and the dissimilarities correspond to those resulting from literature analysis (Ford and Peeper, 2008; Getz, 2003; Mutschlechner, 2012; Palmer and Bejou, 1995). This can be caused by the divergent origin of institutions on both continents and the longer history of entities in the USA and Canada may contribute to higher employment and annual budget, as well as to the wider set of attracting events (political, sport, cultural besides the business ones). European CB are more diversified in their organisational forms. Such a situation probably refers to the different legal and political conditions in other countries and the existence of similar institutions at regional or national level. It should be noted that only a few differences were indicated in the survey and this topic needs further in-depth studies, including the reasons of divergence, too.

However, the organisational differences are not reflected in the operational area and the contrast in the case of tasks and roles is not as sharp and clear as can be supposed. The study in this area stands in contrast to research by Palmer and Bejou (1995), who claim that there is a difference between USA and UK institutions. Roles and tasks of European and 
North American CB are similar and differences probably lie in the range of activity and the way in which they fulfil their detailed responsibilities. It might be only assumed that activity of $\mathrm{CB}$ and visitors bureaux is more diffused because of the wider scope of operation (combining managing business and leisure tourism).

Nonetheless, two roles are clearly distinguished from others: the function of the agent and marketer and these two were characterised by the highest importance and performance, which is also the case for CB from Europe. North American institutions are a little bit more active in attracting meetings, because searching for request for proposals is more important than answering the inquiries. In both groups, less attention was paid to the role of representative, which mostly consists in indicating the meaning of the meetings industry in a city. Apparently, this results from the long history of CB in the USA and Canada, but the same situation occurs in European institutions. Therefore, a well-established position of convention bureau in a particular city may be behind such a state of affairs. Moreover, part of entities in Europe acts as a department of public authority and perhaps they are automatically involved in mediating in relationships between local government and entrepreneurs.

The priority roles of the agent and marketer assume that CB can achieve the greatest by concentrating on bidding following the three strategies listed by Getz (2003). Focus on these functions should result in attracting a higher number of more valuable meetings and lead to the development of a city (Gartrell, 1988; webinar). This is also a suggestion as to what kind of tasks new institutions or organisations should take on in the first place. It is necessary to participate in international competition. Other responsibilities may have a different meaning in cities with a differing level of development of the local meetings industry. Moreover, excellent performance in both bidding for meetings and other services can be a source of competitive advantage.

\section{Conclusion}

This paper contributes to the scientific literature on the roles of CB by identifying differences between organisations in North America and Europe. The research results show that both group of institutions play similar roles, but entities differ mostly in how they evaluate particular tasks. The dissimilarities are probably more a result of local conditions (e.g. structure of meetings industry) in a city that a convention bureau represents than common history of foundation on one or another continent. However, the operational differences are strongly apparent, especially when annual budget or number of full-time employees is compared.

When all the matters are taken into consideration, it can be stated that setting up a new convention bureau or functioning of an institution with very limited resources should be primarily focused on fulfilling tasks typical of the role of an agent and marketer. Also, the organisational form should be chosen wisely to enable playing these two roles. Nonetheless, at the beginning of operation, local entrepreneurs, government and other institutions may need to be integrated; therefore, CB may put more effort into communication, building relationships in the meetings industry, representing it in a city and coordinating joint activities. City promotion, answering the inquires, searching for request for proposals and making bids should be convention bureau's priority, and the meaning of other tasks probably depend on local circumstances.

Therefore, activity of $\mathrm{CB}$ needs further examination. Analysis of operational forms (public-private partnership and local government unit) rather than geographical location may show clearer and sharper differences. Managers should be asked about barriers, because they might want to undertake some activities, but for particular reasons they cannot do that. In this research, it was assumed that limited resources narrow operational scope, but this may require more attention. Support of local government, engagement of 
entrepreneurs and existence of tourism dedicated $\mathrm{DMO}$, convention bureau at regional or national level and other similar institutions may have a strong impact on activities of a particular convention bureau and should be included in analysis of local circumstances. Another issue that needs investigation is a point of view of stakeholders concerning the function of $\mathrm{CB}$ - how they see the role of such an institution and which tasks are the most useful for them. A survey concentrated on this topic will probably be valuable for both: researchers and practitioners.

The survey presented in this paper was conducted on a relatively small sample and it included a limited list of potential differences. The IPA also has its limitations. Some issues like the definitions of importance, a correlation among attributes or interpretation of the results are debatable (Oh 2001). However, this research attempts at analysing differences between CB and it suggests which tasks and roles should be treated as priorities and which ones have supplementary or marginal meaning. The IPA may also suggest that concentration on some tasks (e.g. strong focus on conducting research) may create a chance to stand out and build competitive advantage. Therefore, despite its limitations, the author believes that the proposed examination provided insight into the importance of analysis on the convention bureau's roles and its comparison among different countries or continents.

\section{Notes}

1. Searching for the phrases, convention bureau" or "cvb" in papers' titles, abstracts and/or keywords in field of Business, Management and Accounting (12.07.2018).

2. Former Destination Marketing Association International (Dienst, 2017).

3. However, some European institutions capture both markets as CVBs and in the USA, CBs and DMOs can work separately in the same city.

4. However, this is an oversimplification according to data collected by European Cities Marketing (2020a).

5. This is a small sample taking into account that according to Destinations International (DMAl's empowerMINT.com, 2016) there are ca. 1,450 CVBs in the USA and European Cities Marketing (2020b) has more than 100 city members. However, this is a pioneer study and findings are limited to the participant institutions.

\section{References}

Baloglu, S. and Love, C. (2005), "Association meeting planners' perceptions and intentions for five major US convention cities: the structured and unstructured images”, Tourism Management, Vol. 26 No. 5, pp. 743-752.

Beaver, A. (2005), A Dictionary of Travel and Tourism Terminology, 2nd ed., CABI Publishing, Oxon.

Caber, M., Albayrak, T. and Matzler, K. (2012), "Classification of the destination attributes in the content of competitiveness (by revised importance-performance analysis)", Journal of Vacation Marketing, Vol. 18 No. 1, pp. 43-56.

Cobos, L.M., Wang, Y. and Okumus, F. (2009), "Assessing the web-based destination marketing activities: a relationship marketing perspective", Journal of Hospitality Marketing \& Management, Vol. 18 No. 4, pp. 421-444.

Crouch, G.I. and Weber, K. (2002), "Marketing of convention tourism", in Weber, K. and Chon, K.-S. (Eds), Convention Tourism. International Research and Industry Perspectives, The Haworth Hospitality Press, New York, NY, London, pp. 57-78.

Davidson, R. and Keup, M. (2014), "The use of web 2.0 as a marketing tool by European convention bureaux", Scandinavian Journal of Hospitality and Tourism, Taylor \& Francis, Vol. 14 No. 3, pp. 234-254.

Destinations International (2019), Destination NEXT: Futures Study 2019. A Strategic Road Map for the Next Generation of Global Destination Organizations, Destinations International Foundation. 
Destinations International (2020), "Destination organization performance reporting", available at: https:// destinationsinternational.org/destination-organization-performance-reporting (accessed 30 April 2020).

Dienst, J.N. (2017), "Goodbye, DMAI. Hello, destinations international”, available at: www.pcma.org/ goodbye-dmai-hello-destinations-international/ (accessed 15 June 2020).

DMAI (2015), "2015 DMO organizational and financial profile study", Destination Marketing Association International.

DMAI's empowerMINT.com (2016), "Demystifying industry acronyms: DMO, CVB, DMC - what's the difference?", available at: www.youtube.com/watch?v=3qVDIL29Bow (accessed 30 April 2020).

Enright, M.J. and Newton, J. (2004), "Tourism destination competitiveness: a quantitative approach", Tourism Management, Vol. 25 No. 6, pp. 777-788.

European Cities Marketing (2020a), "ECM meetings statistics raport", available at: www.europeancitiesmarketing. com/ecm-meetings-statistics-report/ (accessed 15 June 2020).

European Cities Marketing (2020b), "Member search", available at: www.europeancitiesmarketing.com/ members-2/?member_type\%5B\%5D=City (accessed 15 June 2020).

Fall, L.T. (2004), "The increasing role of public relations as a crisis management function: an empirical examination of communication restrategising efforts among destination organisation managers in the wake of 11th September, 2001", Journal of Vacation Marketing, Vol. 10 No. 3, pp. 238-252.

Feng, R., Morrison, A.M. and Ismail, J.A. (2004), "East versus west: a comparison of online destination marketing in China and the USA", Journal of Vacation Marketing, Vol. 10 No. 1, pp. 43-56.

Ford, R.C. (2011), "Friends to grow and foes to know: lessons in successful stakeholder management from OrlandoAn interview with William C. Peeper, president (retired), Orlando/orange county convention and visitors bureau", International Journal of Contemporary Hospitality Management, Vol. 23 No. 5, pp. 696-712.

Ford, R.C. and Peeper, W.C. (2007), "The past as prologue: predicting the future of the convention and visitor bureau industry on the basis of its history", Tourism Management, Vol. 28 No. 4, pp. 1104-1114

Ford, R.C. and Peeper, W.C. (2008), "Managing destination marketing organization", The Tasks, Roles, Responsibiliies of the Convention and Visitors Bureau Executive, ForPer Publications, Orlando, FL.

Ford, R.C. and Peeper, W.C. (2009), "Skills, training, and experiences associated with success in the role of a convention and visitors bureau executive: an exploratory study", Journal of Convention \& Event Tourism, Vol. 10 No. 1, pp. 1-26.

Ford, R.C., Gresock, A.R. and Peeper, W.C. (2011), "Board composition and CVB effectiveness: engaging stakeholders that can matter", Tourism Review, Vol. 66 No. 4, pp. 4-17.

Gartrell, R.B. (1988), Destination Marketing for Convention and Visitors Bureaus, Kendall/Hunt Publishing Company, IA.

Gartrell, R.B. (1992), "Convention and visitor bureaus: current issues in management and marketing", Journal of Travel \& Tourism Marketing, Vol. 1 No. 2, pp. 71-78.

Getz, D. (2003), "Bidding on events: identifying event selection criteria and critical success factors", Journal of Convention \& Exhibition Management, Vol. 5 No. 2, pp. 1-24.

Getz, D., Anderson, D. and Sheehan, L. (1998), "Roles, issues, and strategies for convention and visitors' bureaux in destination planning and product development: a survey of Canadian bureaux", Tourism Management, Vol. 19 No. 4, pp. 331-340.

Go, F. and Zhang, W. (1997), "Applying importance-performance analysis to Beijing as an international meeting destination", Journal of Travel Research, Vol. 35 No. 4, pp. $42-49$.

Golden-Romero, P. (2007), Hotel Convention Sales, Services, and Operations, Butterworth-Heinemann, Amsterdam, Boston, Heidelberg, London, New York, NY, Oxford, Paris, San Diego, San Francisco, Singapore, Sydney, Tokyo.

$\mathrm{Ha}, \mathrm{M}$. and Love, C. (2005), "Exploring content and design factors associated with convention and visitors bureau web site development", Journal of Convention \& Event Tourism, Vol. 7 No. 1, pp. 43-59.

Harrill, R. and Stringam, B. (2008), "From sales tool to site development: the evolution of destination marketing on the web", Tourism Analysis, Vol. 13 No. 3, pp. 295-307. 
Kovačević, I. (2017), "Convention bureau perspectives on destination management: identification and classification of activities", Ekonomika Preduzeća, Vol. 65 Nos 3/4, pp. 259-263.

Lee, M.J. and Lee, K.M. (2006), "Convention and exhibition center development in Korea", Journal of Convention \& Event Tourism, Vol. 8 No. 4, pp. 101-120.

Lee, H.-R., Lee, J.-S. and Jones, D. (2015), "Exploring the interrelationship between convention and visitor bureau (CVB) and its stakeholders, and CVB performance from the perspective of stakeholders", Journal of Travel \& Tourism Marketing, Vol. 8408, pp. 1-26.

Leszczyński, G., Zieliński, M. and Zmyślony, P. (2015), "The borderline of complexity of business tourism product - needs of customers or interactions of suppliers?", 31th Annual IMP Conference "Organizing Sustainable BtoB Relationships - Designing in Changing Networks", Kolding (Denmark), 25-29 August 2015.

Loomis, C. (2018), "CVB update: your wish is their command", available at: www.themeetingmagazines. com/cit/cvb-update-wish-command/ (accessed 30 April 2020).

Maier, T.A. and Johanson, M. (2013), "An empirical investigation into convention hotel demand and ADR trending", Journal of Convention \& Event Tourism, Vol. 14 No. 1, pp. 2-20.

Marques, J. and Santos, N. (2017), "Business tourism development: a Portuguese perspective | Desarrollo del turismo de negocios: una perspectiva Portuguesa", Cuadernos de Turismo, No. 40, pp. 423-437.

Martilla, J.A. and James, J.C. (1977), "Importance-performance analysis", Journal of Marketing, Vol. 41 No. 1, pp. 77-79.

Masberg, B.A. (1998), "Defining the tourist: is it possible? A view from the convention and visitors bureau", Journal of Travel Research, Vol. 37 No. 1, pp. 67-70.

Masberg, B.A. (2000), "What is the priority of research in the marketing and promotional efforts of convention and visitors bureaus in the United States? What is the priority of research in the marketing and promotional efforts of convention and visitors bureaus in the united", Journal of Travel \& Tourism Marketing, Vol. 8 No. 2, pp. 29-40.

Mihalic, T. (2013), "Performance of environmental resources of a tourist destination: concept and application", Journal of Travel Research, Vol. 52 No. 5, pp. 614-630.

Morrison, A.M. (2019), Marketing and Managing Tourism Destinations, Routledge Taylor \& Francis Group, London, New York, NY.

Morrison, A.M., Bruen, S.M. and Anderson, D.J. (1998), "Convention and visitor bureaus in the USA: a profile of bureaus, bureau executives, and budgets", Journal of Travel \& Tourism Marketing, Vol. 7 No. 1 , pp. 1-19.

Mutschlechner, C. (2012), "ICCA Sector Destination Marketing Survey 2012 (including historical data 1994-2007)", ICCA.

Ogonowska, M. (2017), "Convention and visitors bureau: a key intermediary in the meetings industry", Global Intermediation and Logistics Service Providers, IGI Global, pp. 226-241.

Oh, H. (2001), "Revisiting importance-performance analysis", Tourism Management, Vol. 22 No. 6, pp. 617-627.

Palmer, A. and Bejou, D. (1995), "Tourism destination marketing alliances", Annals of Tourism Research, Vol. 22 No. 3, pp. 616-629.

Park, S. and Kim, D.Y. (2017), "Assessing language discrepancies between travelers and online travel recommendation systems: application of the Jaccard distance score to web data mining", Technological Forecasting and Social Change, Elsevier, Vol. 123, pp. 381-388.

Rogers, T. (2013), Conferences and Conventions: A Global Industry, 3rd ed., Routledge: Taylor \& Francis Group, London and New York, NY.

Seiser, B. (2008), European City Tourism Organisations. How City Tourism Organisations in Europe Prepare Themselves for Rough Times in Saturated Markets, VDM Verlag Dr Muller Aktiengesellschaft \& Co. KG.

Slaton, H.R. (2013), "What DMOs are doing to stand out", available at: www.pcmaconvene.org/features/ what-dmos-are-doing-to-stand-out/ (accessed 15 June 2020).

Spiller, J. (2002), "History of Convention Tourism", in Weber, K. and Chon, K.-S. (Eds), Convention Tourism. International Research and Industry Perspectives, The Haworth Hospitality Press, New York, NY, London, pp. 3-20. 
Stepchenkova, S., Tang, L., Jang, S.(S.)., Kirilenko, A.P. and Morrison, A.M. (2010), "Benchmarking CVB website performance: spatial and structural patterns", Tourism Management, Vol. 31 No. 5, pp. 611-620.

Swarbrooke, J. and Horner, S. (2001), Business Travel and Tourism, Butterworth-Heinemann, Oxford.

UNWTO (2010), Survey on Destination Governance, Evaluation Report, Madrid.

Vallee, P. (2008), "Convention and visitors bureaus: partnering with meeting managers for success", in Ramsborg, G.C., Miller, B., Breiter, D., Reed, B.J. and Rushing, A. (Eds), Professional Meeting Management, Comprehensive Strategies for Meetings, Conventions and Events, Kendall/Hunt, Chicago, IL, pp. 161-178.

Wang, Y. (2008), "Collaborative destination marketing: roles and strategies of convention and visitors bureaus", Journal of Vacation Marketing, Vol. 14 No. 3, pp. 191-209.

Wang, Y. and Fesenmaier, D.R. (2007), "Collaborative destination marketing: a case study of Elkhart county, Indiana", Tourism Management, Vol. 28 No. 3, pp. 863-875.

Wang, Y. and Russo, S.M. (2007), "Conceptualizing and evaluating the functions of destination marketing systems”, Journal of Vacation Marketing, Vol. 13 No. 3, pp. 187-203.

Weber, K. (2001), "Meeting planners' use and evaluation of convention and visitor bureaus", Tourism Management, Vol. 22 No. 6, pp. 599-606.

Wood, J.T. (2002), How the Distribution of the Hotel Bed Tax Impacts the Destination Marketing Organization, Providence, RI, Unpublished manuscript.

Xiang, Z., Pan, B., Law, R. and Fesenmaier, D.R. (2010), "Assessing the visibility of destination marketing organizations in google: a case study of convention and visitor bureau websites in the United States", Journal of Travel \& Tourism Marketing, Vol. 27 No. 7, pp. 694-707.

Yuan, Y.L., Gretzel, U. and Fesenmaier, D.R. (2006), "The role of information technology use in American convention and visitors bureaus", Tourism Management, Vol. 27 No. 2, pp. 326-341.

\section{Corresponding author}

Natalia Latuszek can be contacted at: natalia.latuszek@ue.poznan.pl

For instructions on how to order reprints of this article, please visit our website: www.emeraldgrouppublishing.com/licensing/reprints.htm

Or contact us for further details: permissions@emeraldinsight.com 